\title{
BEHAVIOR OF THE NON-SELECTIVE HERBICIDE GLYPHOSATE IN AGRICULTURAL SOIL
}

\author{
${ }^{1,2}$ Abdul Jabbar Al-Rajab and ${ }^{3}$ Othman M. Hakami \\ ${ }^{1}$ Center of Research and Environmental Studies, Jazan University, Jazan, Saudi Arabia \\ ${ }^{2}$ Laboratory of Soil and Environmental Sciences, \\ UMR 1120 INPL/ENSAIA-INRA; 54505 Vandoeuvre-lès-Nancy Cedex, France \\ ${ }^{3}$ Department of Chemistry, Faculty of Science, \\ Jazan University, Jazan, Saudi Arabia
}

Received 2014-02-25; Revised 2014-02-26; Accepted 2014-03-15

\begin{abstract}
Glyphosate [ $N$-phosphonomethyl]glycine is a systematic, non-selective, organophosphorus herbicide used worldwide in agriculture and industrial zones. Following its application, residues of glyphosate can threaten soil or aquatic organisms in adjacent water. In this study, we followed the degradation, stabilization, remobilization and leaching of ${ }^{14} \mathrm{C}$-glyphosate in three agricultural soils in laboratory incubations and in lysimeters under field conditions. Glyphosate degradation was relatively rapid with a half-life of 14.5 days in the silt clay loam soil incubated at $20^{\circ} \mathrm{C}$. Glyphosate's degradation product, Aminomethylphosphonic Acid (AMPA), represented more than $85 \%$ of residues after 80 days of laboratory incubation. Leaching of glyphosate in lysimeters of three different investigated soils under outdoor conditions was very slow, less than $1 \%$ of the initial applied amount has been detected in the leachates after 100 days of experimentation. Glyphosate rapidly formed non-extractable residues after treatment. In summary, glyphosate was removed from soil very rapidly and its leaching seems to be very slow regardless the type of treated soil. On the other hand, the contamination risk of groundwater with its metabolite AMPA at long term is probably due to the release of the non-extractable residues.
\end{abstract}

Keywords: Glyphosate, AMPA, Soil, Persistence, Leaching

\section{INTRODUCTION}

Glyphosate $[N$-phosphonomethyl $]$ glycine is a nonselective organophosphorous herbicide, the most used active ingredient worldwide in agricultural, silvicultural and industrial zones (Kryuchkova et al., 2014; Van Stempvoort et al., 2014; Moreno et al., 2013). Introducing the transgenic crops (maize, cotton, potatoes and soybean) resistant to glyphosate was an additional factor to increase dramatically its use worldwide (Aparicio et al., 2013; Panettieri et al., 2013; Imfeld et al., 2013; Abubakar et al., 2011; Wiatrak and Chen, 2011; Mercurio et al., 2014). Detection of glyphosate and its principal degradation product Aminomethylphosphonic Acid (AMPA) in water resources has been reported in several studies albeit at low concentrations (Coupe et al., 2012; Malaguerra et al., 2013). However, information on the residues dynamics of glyphosate and AMPA in agricultural soil is still scarce. Extraction and determination of glyphosate is an analytical challenge because of its high solubility (about $10.5 \mathrm{~g} \mathrm{~L}^{-1}$ in water) and its other physico-chemical properties: Log Koc values (3.4-3.7), half-life varies from 6 to 10 weeks in water and from 1 to 9 weeks in soil (Botero-Coy et al., 2013; Coupe et al., 2012; Struger et al., 2008). After the application of glyphosate for weed control, a part of herbicide reaches the target plants and another part settles on the soil. Therefore, a part of glyphosate will be absorbed by the soil constituent and another part will still available in the soil solution (Guimont et al., Corresponding Author: Abdul Jabbar Al-Rajab, Center of Research and Environmental Studies, Jazan University, Jazan, Saudi Arabia Tel: +15149008543 
2005). The available residues of glyphosate in soil solution will be either mineralized or transferred to groundwater through the soil. The physicochemical properties of the soil, its biological activity and other chemical and biochemical reactions lead to the degradation of the herbicide (Al-Rajab et al., 2008).

Degradation of glyphosate is relatively rapid in the soil, which could be a limiting factor to contaminate the solution of soil and groundwater by glyphosate (Van Stempvoort et al., 2014). On the other hand, this rapid degradation could increase the risk of pollution by its metabolites: AMPA and sarcosine (Al-Rajab et al., 2008; Landry et al., 2005). Only the complete mineralization of a pesticide could eliminate its risk for a potential environmental pollution (Getenga, 2004). Glyphosate is strongly adsorbed to soil with $\mathrm{K}_{\mathrm{f}}$ values between 16.6 and 34.5 (Coquet, 2003; Al-Rajab et al., 2008). The strong sorption of glyphosate to soil and the rapid formation of non-extractable residues increase the stabilization of compound in the soil and decrease the short term water pollution (Landry et al., 2005). These residues could be remobilized at long term and could reach the groundwater at low concentrations (Al-Rajab et al., 2010a; Coupe et al., 2012; Candela et al., 2007).

Detection of glyphosate and its metabolite AMPA in water resources have been reported in France during the years 2003-2004 at concentrations higher than $0.1 \mu \mathrm{g} \mathrm{L}^{-1}$ which is the EC limit (Landry et al., 2005). The occurrence of glyphosate in the surface water in southern Ontario (Canada) has been reported in 2008 showing that the detected concentrations of glyphosate were $<65 \mu \mathrm{g}$ $\mathrm{L}^{-1}$ in a total of 502 samples collected during 2 years (Struger et al., 2008). Glyphosate and AMPA were detected in Canadian riparian groundwater samples collected in 2009 at maximum concentrations of 0.042 and $2.87 \mu \mathrm{g} \mathrm{L}^{-1}$ for glyphosate and AMPA respectively (Van Stempvoort et al., 2014). Also, detection of glyphosate has been reported in about 20 streams in midwestern states at concentration above $0.1 \mu \mathrm{g} \mathrm{L}^{-1}$ and $83 \%$ of streams had detectable concentrations of AMPA (Battaglin et al., 2005).

Information on residue dynamics of glyphosate in different types of soil is scarce. Within this context, our objectives in this study were to gather information concerning the persistence, dissipation pathways, leaching, stabilization and remobilization of glyphosate in soil.

\section{MATERIALS AND METHODS}

\subsection{Chemicals}

[Phosphonomethyl- ${ }^{14} \mathrm{C}$ ]-glyphosate diluted, purity 99\% was purchased from ARC-ISOBIO (Belgium).
Glyphosate [N-phosphonomethyl]glycine, purity 99\% was purchased from Cluzeau (CIL, Paris). Aminomethylphosphonic Acid (AMPA), $10 \mathrm{ng} \mu \mathrm{L}^{-1}$ in water, was purchased from (Dr. Ehrenstorfer $\mathrm{GmbH}$, Germany). Sarcosine [ $N$-methylglycine], purity $99 \%$ was purchased from Fluka (Germany). $\mathrm{H}_{2} \mathrm{PO}_{4}$, FMOCchloride, Potassium hydroxyde and Sodium tetraborate decahydrate were purchased from Fluka (Germany). Methanol and acetonitrile (HPLC grade) were purchased from SDS (France).

\subsection{Sampling}

Soils used in this study were obtained from three different agricultural lands in Lorraine region (France). Therefore, based on information provided by the landowners, these soils were never exposed to direct agricultural application of glyphosate and their properties were as following: Sandy loam soil (sand:Silt:Clay (59:30:11), pH 5.1; \% organic matter 0.82$)$; silt clay loam soil (sand:Silt:Clay (16:53:31), pH 6.3; \% organic matter 1.45); and clay loam soil (sand:Silt:Clay (35:30:35), pH 7.9; \% organic matter 1.91).

In the laboratory studies, soils were air dried then sieved at $2 \mathrm{~mm}$ and stored in fridge at $4^{\circ} \mathrm{C}$ until treatment. Otherwise, in the outdoor leaching study, lysimeters were prepared in site using an undisturbed soil for each type of soil separately, a total of 7 columns of each soil were used in this study. Lysimeters were polyvinyl chloride pipes of $10 \mathrm{~cm}$ wide and $35 \mathrm{~cm}$ long. Therefore, the 21 lysimeters of the three selected soils were placed in the experimental field of ENSAIA (54500 Vandoeuvre-lès-Nancy, France) for 100 days.

\subsection{Extraction of Glyphosate}

The efficacy of different solvents for extraction of glyphosate from soil was evaluated as follows. A $5 \mathrm{~g}$ portion of each soil (in triplicate) was treated with a 0.5 $\mathrm{mL}$ solution of $\mathrm{H}_{2} \mathrm{O}$ (concentration of $19.4 \mathrm{~Bq} \mathrm{~g}^{-1}$ ) of [Phosphonomethyl- ${ }^{14} \mathrm{C}$ ]-glyphosate and $0.1 \mu \mathrm{g} \mathrm{g}^{-1}$ of unlabelled glyphosate. Treated soil was placed into a 250 mL PPCO (Nalgene $\AA$, VWR, USA) centrifuge bottle and $25 \mathrm{~mL}$ of selected solvent were added. Five different solvents were tested separately for the glyphosate extraction efficacy: Ammonium oxalate monohydrate $0.1 \mathrm{M}$; potassium dihydrogen phosphate $\left(\mathrm{KH}_{2} \mathrm{PO}_{4}\right) 0.1 \mathrm{M}$; a mixture of $\left(\mathrm{NH}_{4} \mathrm{OH} \quad 0.5 \mathrm{M}+\mathrm{KH}_{2} \mathrm{PO}_{4} \quad 0.1 \mathrm{M}+\mathrm{H}_{3} \mathrm{PO}_{4}\right.$ $0.5 \%) ; \mathrm{CaCl}_{2} 0.1 \mathrm{M}$ and distilled water. Bottles were rotary shaken for $2 \mathrm{~h}$, then centrifuged at $5000 \mathrm{~g}$ for 20 min, the supernatant of each sample was recovered. Extraction of each sample as been repeated twice, the supernatants of the same sample were combined and a portion of $1 \mathrm{~mL}$ counted by Liquid Scintillation Counter 
(LSC). Thereafter, extraction of glyphosate from soil samples was effectuated with $\left(\mathrm{KH}_{2} \mathrm{PO}_{4}\right) 0.1 \mathrm{M}$.

\subsection{Laboratory Degradation Study}

About 25-g soil samples were placed in glass jars (60 $\mathrm{mm}$ diameter $\times 40 \mathrm{~mm}$ high). Samples of silt clay loam soil were prepared in triplicates for each sampling time. Each sample was amended by $0.51 \mathrm{mg}$ of glyphosate and $45.1 \mathrm{kBq}$ in water. Final soil moisture was $80 \%$ of the soil retention capacity. After treatment, each sample was added to a Mason jars $(1.5 \mathrm{~L})$. At the same time, a plastic vial of $10 \mathrm{~mL} \mathrm{H}_{2} \mathrm{O}$ was added to each jar in order to maintain the humidity of soil (Al-Rajab et al., 2009). Another plastic scintillation vial with $10 \mathrm{~mL}$ of $0.5 \mathrm{~N}$ $\mathrm{NaOH}$ was placed into each jar for trapping ${ }^{14} \mathrm{CO}_{2}$. Jars were incubated at $20^{\circ} \mathrm{C}$ in the dark for 80 days. The radioactivity trapped in $\mathrm{NaOH}$ was counted at each sampling time using a Liquid Scintillation Counter LSC Packard Tri-Carb 1900 CA (Packard, USA). $1 \mathrm{~mL}$ of $\mathrm{NaOH}$ was added to $10 \mathrm{~mL}$ of scintillation cocktail in a plastic scintillation vial to measure the radioactivity in the LSC during $10 \mathrm{~min}$. At each sampling date, the $25-\mathrm{g}$ soil samples were extracted separately using $\mathrm{KH} 2 \mathrm{PO} 4$ as described previously. Then, after the 3rd and last extraction, soil samples were air-dried at the lab ambient temperature for 3 days. The remaining ${ }^{14} \mathrm{C}$-radioactivity in the samples after extraction was referred as (non-extractable residues) which was determined by combustion at $900^{\circ} \mathrm{C}$ using a 307 Packard Oxidiser (Packard, USA).

\subsection{Leaching Study}

Lysimeters were prepared and placed in the experimental field of Lorraine University (France) 3 months before the treatment. During the experimentation of 100 days, the average temperature was $10^{\circ} \mathrm{C}$; total precipitation was $235 \mathrm{~mm}$; in total 8 leachates samples were collected. Leached radioactivity from each lysimeter was determined directly after collection, Therefore, water samples were stored at $-18^{\circ} \mathrm{C}$ until analysis.

\subsection{Analytical Methods}

${ }^{14} \mathrm{C}$-Radioactivity has been determined using a Liquid Scintillation Counter LSC. Glyphosate residues were determined using a Varian HPLC (USA) equipped with two detectors: A fluorescence detector and a $\beta$-radioactivity detector. A Lichrosorb $\left(\mathrm{NH}_{2}\right)$ column $(4 \times 250 \mathrm{~mm}, 5 \mu \mathrm{m})$ purchased from (CIL-Cluzeau, France) was used and thermostated at $30^{\circ} \mathrm{C}$. Fluorescence detector was set at $(\lambda$ 260 and $310 \mathrm{~nm}$ ), while the flow rate of $1.2 \mathrm{~mL} \mathrm{~min}^{-1}$ was adopted in the $\beta$-radioactivity detector with a counting cell of $500 \mu \mathrm{L}$. The mobile phase was a mixture of $\left(\mathrm{KH}_{2} \mathrm{PO}_{4}\right.$ $\left.0.05 \mathrm{~mol} \mathrm{~L}^{-1}, \mathrm{pH} 5.7\right) /$ acetonitrile $(70 / 30: \mathrm{V} / \mathrm{V})$ at flow rate of $0.8 \mathrm{~mL} \mathrm{m^{-1 }}$. The injected volume was $50 \mu \mathrm{L}$. Within these conditions, the retention times were 4.2, 6.6 and 13.3 for sarcosine, AMPA and glyphosate respectively. Determination of the non-extractable residues in soil has been effectuated by combustion of $0.5 \mathrm{~g}$ portions at $900^{\circ} \mathrm{C}$ using an oxidizer (Packard, USA).

Statistical analyses were conducted using Stat Box (Version 6.4, Grimmer Software, France).

\section{RESULTS}

\subsection{Extraction of Glyphosate}

Extraction recovery of glyphosate varied from 4 to $74 \%$ of the initial applied amount (Table 1). $\mathrm{CaCl}_{2}(0.1$ $\mathrm{M})$ and water were the less effective solvents in glyphosate extraction in the three investigated soils. However, ammonium oxalate $(0.1 \mathrm{M})$ was the most efficient solvent with a recovery rate ranged from 60 to $74 \%$. The only issue with the extraction with ammonium oxalate that the extracts were very dark and need an intensive clean up. On the other hand, potassium dihydrogen phosphate $\left(\mathrm{KH}_{2} \mathrm{PO}_{4} 0.1 \mathrm{M}\right)$ was adopted as a suitable solvent since the extracts were clear and it showed an acceptable recovery rate varied from 45 to $49 \%$ in investigated soils (Table 1). Recovery rate with citric acid (20\%) was not high enough (less than 37\%) for the three investigated soils.

\subsection{Dissipation of Glyphosate}

Results showed an immediate and high degradation rate of glyphosate after its application on the soil (Fig. 1). Mineralization of glyphosate after 17 days of incubation reached $39.7 \%$ of the initial amount applied. Thereafter, the mineralization of glyphosate declined gradually. The half-life of glyphosate derived from the mineralization rates was 31 days for silt clay loam soil. However, the extraction curves are opposite to those of the mineralization (Fig. 2).

The percentage of extracted residues from the silt clay loam soil at T0 was only $56.9 \pm 0.7 \%$. This availability to extraction decreased overtime, it reached $6.9 \%$ of the initial amount for silt clay loam soil. HPLC analysis showed the appearance of two degradation products of glyphosate AMPA and sarcosine. However, this analysis of glyphosate residues by HPLC did not allow us to measure the sarcosine because its retention time was too short and equal that of co-eluted and unlabelled organic compounds. The half-life of glyphosate extractable was 14.5. 
Table 1. Extraction efficiency of glyphosate from the selected soils using different solvents Extraction efficiency (\%: Mean \pm standard deviation: $\mathrm{n}=3$ )

\begin{tabular}{llll} 
Solvent & Sandy loam & Silt clay loam & Clay loam \\
\hline $\mathrm{KH}_{2} \mathrm{PO}_{4}(0.1 \mathrm{M})$ & $44.9( \pm 0.3)$ & $48.8( \pm 0.7)$ & $48( \pm 0.5)$ \\
Ammonium oxalate $(0.1 \mathrm{M})$ & $59.9( \pm 0.7)$ & $73.5( \pm 0.2)$ & $61.1( \pm 0.1)$ \\
Citric acid $(20 \%)$ & $34.2( \pm 0.1)$ & $36.4( \pm 0.2)$ & $28.9( \pm 0.2)$ \\
$\mathrm{CaCl}_{2}(0.1 \mathrm{M})$ & $5.7( \pm 0.5)$ & $3.6( \pm 0.9)$ & $10.3( \pm 0.6)$ \\
$\mathrm{H}_{2} \mathrm{O}$ & $14.3( \pm 0.2)$ & $23.5( \pm 0.1)$ & $31.7( \pm 0.1)$ \\
\hline
\end{tabular}

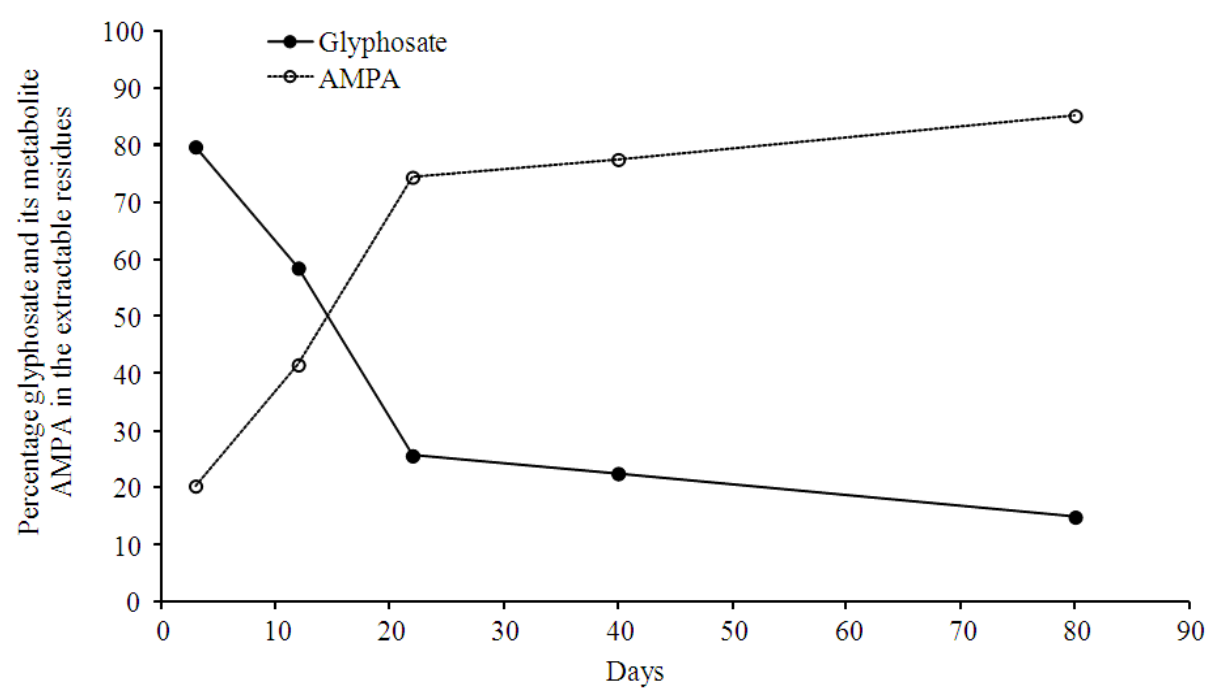

Fig. 1. Residues evolution of glyphosate and AMPA in the extractable residues in silt clay loam soil during incubation at $20^{\circ} \mathrm{C}$

घ Extractable radioactivity $\mathrm{a}$ Mineralization as ${ }^{14} \mathrm{O}_{2}$ वNon extractable radioactivity

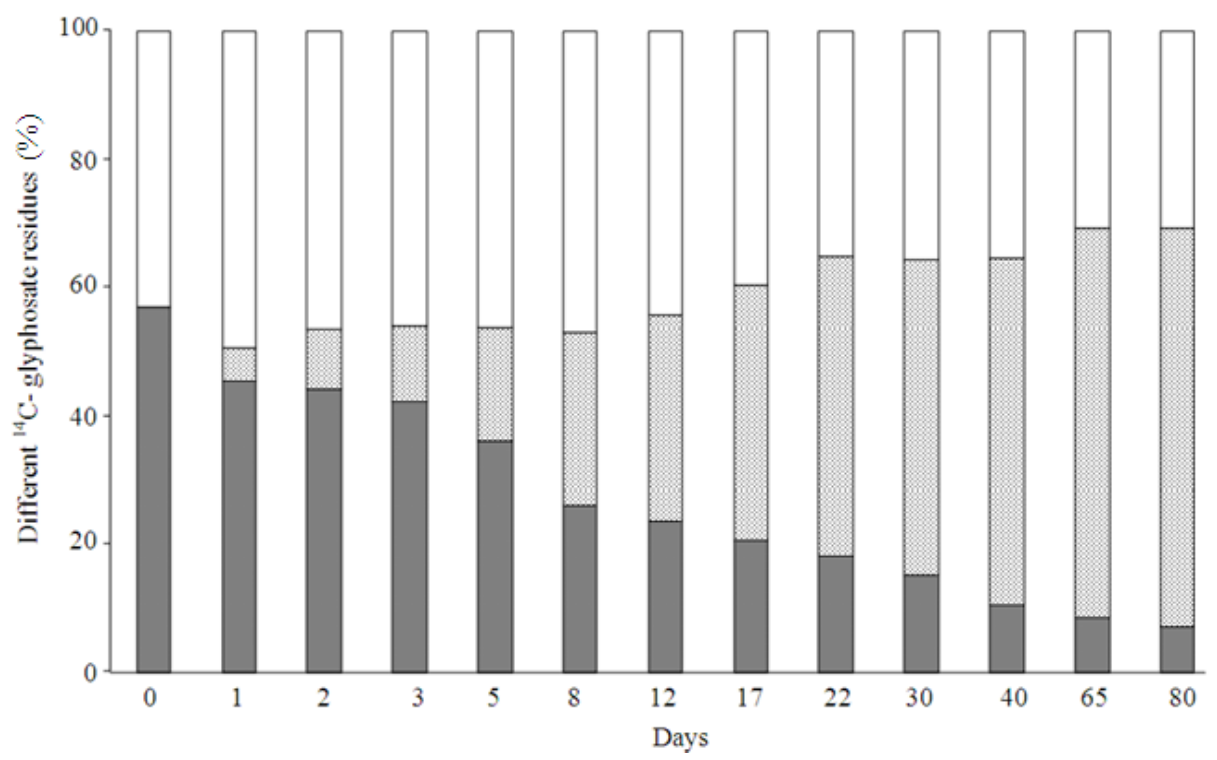

Fig. 2. Evolution of different portions of ${ }^{14} \mathrm{C}$-glyphosate residues (extractable, mineralization as ${ }^{14} \mathrm{CO}_{2}$ and Non extractable) in silt clay loam soil during incubation at $20^{\circ} \mathrm{C}$ 


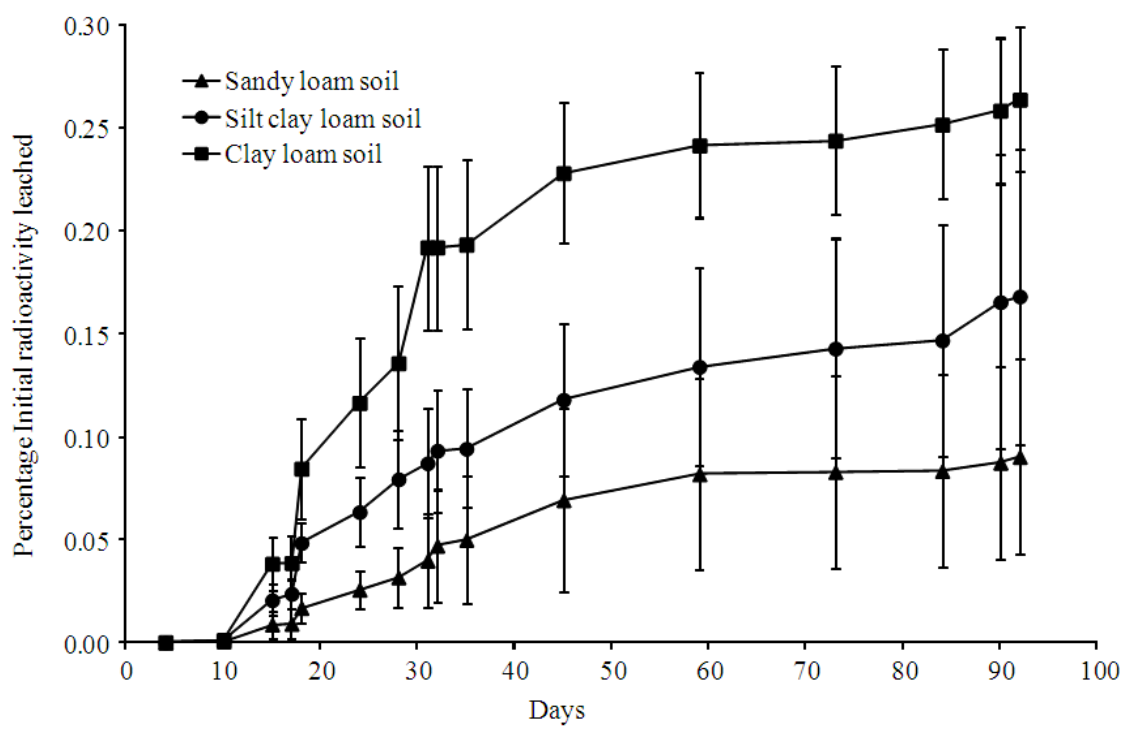

Fig. 3. Radioactivity leached from lysimeters of the investigated soils treated with ${ }^{14} \mathrm{C}$-glyphosate under outdoor conditions

The fraction of non-extractable residues represent the residues which cannot be extracted from the soil by the series of $\mathrm{KH}_{2} \mathrm{PO}_{4}$ extractions (exhaustive extraction) (Fig. 2). The formation of the non-extractable residues NER in the silt clay loam soil reached $43 \%$ of the initial applied amount at $\mathrm{T} 0$ and $49.4 \%$ at $\mathrm{T} 1$. The rate stayed stable until T2 after which it decreased to $30.9 \%$ by the end of experiment.

\subsection{Leaching of Glyphosate}

Our study showed that the residues of glyphosate were detected in the first leachates samples of three soils, the cumulated precipitation was $85 \mathrm{~mm}$. In the case of silt clay loam soil, the maximum residues concentration of $9.5 \pm 7 \mu \mathrm{g}$ $\mathrm{L}^{-1}$ has been reached after 2 months of application. Concentration of leached residues decreased dramatically after 2 months until the end of experiment (Fig. 3).

\section{DISCUSSION}

\subsection{Extraction of Glyphosate}

Extraction and determination of glyohosate in agricultural soil is problematic due to its high solubility and its physic-chemical properties (Botero-Coy et al., 2013). In the present study, extraction recovery of glyphosate varied from 4 to $74 \%$ of the initial applied amount (Table 1). $\mathrm{CaCl}_{2}(0.1 \mathrm{M})$ and water were the less effective solvents in glyphosate extraction in the three investigated soils. However, ammonium oxalate $(0.1 \mathrm{M})$ was the most efficient solvent with a recovery rate ranged from 60 to $74 \%$. The only issue with the extraction with ammonium oxalate that the extracts were very dark and need an intensive clean up. On the other hand, potassium dihydrogen phosphate $\left(\mathrm{KH}_{2} \mathrm{PO}_{4} 0.1\right.$ $\mathrm{M})$ was adopted as a suitable solvent since the extracts were clear and it showed an acceptable recovery rate varied from 45 to $49 \%$ in investigated soils (Table 1), this rate was similar to that one reported by aother studies (Cheah and Lum, 1998; Landry et al., 2005). Recovery rate with citric acid (20\%) was not high enough (less than 37\%) for the three investigated soils. Non-extractable residues of glyphosate in soil increase with the time; consequently, glyphosate will be less available for extraction or degradation.

\subsection{Dissipation of Glyphosate}

Monitoring of mineralization of glyphosate labelled on the phosphonomethyl group allows assessing both the loss of glyphosate and AMPA. We observed an immediate and high degradation rate of glyphosate after its application on the soil (Fig. 1). The absence of lag phase indicates that the microflora of soil already had an enzymatic system capable of degrading glyphosate and as such did not need an adaptation period. Mineralization of glyphosate after 17 days of incubation reached $39.7 \%$ of the initial amount applied. Thereafter, the mineralization of glyphosate declined gradually. The fast mineralization of glyphosate in the soil appears due to its bioavailability. The half-life of glyphosate derived from the mineralization rates was 31 days for silt clay loam soil. On 
the other hand, the effect of organic matter content in the soil on mineralization of glyphosate was not clear under the conditions of this study. The extraction rate of glyphosate is an indication of the accessibility of the residues for microbial degradation and/or their transfer to groundwater under natural conditions. The extraction curves are opposite to those of the mineralization (Fig. 2).

The percentage of extracted residues from the silt clay loam soil at T0 was only $56.9 \pm 0.7 \%$. We can assume that the treatment in a dry soil may cause an entry of glyphosate into the microporisity of aggregates during the capillary invasion by the aqueous solution of treatment (Guimont et al., 2005; Al-Rajab et al., 2010b). The size of this compartment would be defined at the time of treatment and may depend on the physicochemical and physical properties and the moisture rate of soil at the application moment. This availability to extraction decreased overtime, it reached $6.9 \%$ of the initial amount for silt clay loam soil. The evolution of extraction rate with $\mathrm{KH}_{2} \mathrm{PO}_{4}$ over time in the soil is related to the mineralization of residues and the availability of non-extractable residues for mineralization or extraction. A similar behaviour of extractable residues of glyphosate over time was reported by (Getenga, 2004; Miles, 1998). HPLC analysis showed the appearance of two degradation products of glyphosate AMPA and sarcosine. However, this analysis of glyphosate residues by HPLC did not allow us to measure the sarcosine because its retention time was too short and equal that of co-eluted and unlabelled organic compounds.

The appearance of AMPA during the first days of incubation is due the fast mineralization of glyphosate in soil, reaching about $85.1 \%$ of residues after 80 days of treatment (Fig. 1). Our results are consistent, to some extent, with those obtained by (Cheah and Lum, 1998) who reported the rate of AMPA in the extracts of a sandy loam soil increased gradually over incubation time and reached $50 \%$ of residues after 45 days of treatment. The half-life of glyphosate extractable was 14.5 , this value is in accord with the half-lives of 6 to 9 days reported in other study for glyphosate in four agricultural soils incubated at $25^{\circ} \mathrm{C}$ (Eberbach, 1998) as well as the 19.2 days half-life observed in a sandy loam soil by (Cheah and Lum, 1998). However, much longer half-lives have also been reported by (Getenga, 2004) whereby the half-life of glyphosate was 85.6 days in a clay soil.

The fraction of non-extractable residues represent the residues which cannot be extracted from the soil by the series of $\mathrm{KH}_{2} \mathrm{PO}_{4}$ extractions (exhaustive extraction) (Fig. 2). The formation of the non-extractable residues
NER in the silt clay loam soil reached $43 \%$ of the initial applied amount at $\mathrm{T} 0$ and $49.4 \%$ at $\mathrm{T} 1$. The rate stayed stable until T2 after which it decreased to $30.9 \%$ by the end of experiment. The rate of non-extractable residues decreased over time unlike other pesticides such as atrazine where the rate of non-extractable residues increases gradually over dozens of days (Winkelmann, 1991). The rate of non-extractable residues is probably dependent on the properties and physical aspects of the soils including the size of the microporal compartment. This rapid formation of non-extractable residues immediately after treatment is very specific for glyphosate. The treatment of herbicide on a dry soil promotes the capillary invasion and the rapid transport of the solution of treatment in the microporisity intra aggregate, subsequently making the herbicide inaccessible for extraction (Guimont et al., 2005). We also reported that the initiation of the degradation of glyphosate did not affect the evolution of extractable residues rate. The very slow decrease of non-extractable residues showed that these residues can return by diffusion and under the effect of a concentration gradient, to areas accessible to microorganisms to subsequently undergo mineralization.

\subsection{Leaching of Glyphosate}

This study showed that water circulation in the soil might has an important role in contamination of groundwater with glyphosate. The diminution of soil macroporosity on the surface layer (where most residues usually present) with the time slows the water infiltration and might encourage the desorption of glyphosate residues. The circulation of glyphosate residues in soil could be due to a preferential water flow regarding the presence of its residues in the 1st collected leachates (Fig. 3). In disaccording with results reported by (Dousset et al., 2004), our study showed that the residues of glyphosate were detected in the first leachates samples of three soils, the cumulated precipitation was $85 \mathrm{~mm}$. Detection of glyphosate residues in the 1 st leachates was due to the preferential flow (Laitinen et al., 2006). In the case of silt clay loam soil, the maximum residues concentration of $9.5 \pm 7 \mu \mathrm{g} \mathrm{L}^{-1}$ has been reached after 2 months of application. However, (De Jonge and Jacobsen, 2000) have reported residues concentration of glyphosate much higher than what was obtained from the current study.

Concentration of leached residues decreased dramatically after 2 months until the end of experiment (Fig. 3). Our findings were in accord with results reported by (De Jonge and Jacobsen, 2000; Landry et al., 2005) who detected the glyphosate residues in the soil 
leachates after 3 months of application. Overall, the total residues (extractable and non-extractable) of glyphosate in the soil should be considered to evaluate its persistence in the soil, not only the extractable residues.

\section{CONCLUSION}

The present study monitored the residue dynamics of glyphosate in agricultural soil in controlled and outdoor conditions. Results obtained for the fate study suggest that the water pollution with this herbicide is closely related to the adsorption and the formation of nonextractable residues, which are themselves dependent on soil texture and its moisture condition at the time of treatment. In case of rain following treatment, the risk of groundwater pollution by glyphosate will be low but may continue to be present for long time since the mineralization is slow. The silt clay loam soil could be less favourable for water pollution since it showed a formation of large amount of non-extractable residues. In the semi-field lysimeters study, leaching of glyphosate was limited, but its metabolite AMPA seems to be the main potential pollutant of the groundwater. The water circulation mode in the soil was preferential flow which facilitate a fast leaching of residues to reach the groundwater.

In summary, these results suggest that the organophosphorus herbicide glyphosate is rapidly degradable in the agricultural soil. Leaching of glyphosate seems to be very slow regardless the type of the soil. Release of the non-extractable residues of glyphosate probably increases the risk of groundwater pollution with its metabolite AMPA at long term. More investigations are requested for a better understanding of the effect of soil content of organic carbon and soil microflora on environmental behavior of glyphosate.

\section{ACKNOWLEDGEMENT}

The researchers thank the DIREN, AERM and the DRAF of Lorraine (France) for their financial support. We thank Professor Michel Schiavon (ENSAIAINPL/INRA, France) who left our world early for his assistance and technical support. A special thank you to Professor Abdallah Y. Basahy (CRES, Jazan University, KSA) for his continuing support and encouragement.

\section{REFERENCES}

Abubakar, M.S., D. Ahmad, O. Jamarei, S. Samsuddin and M. Norhisam, 2011. Evaluation of a dualpurpose chemical applicator for paddy fields. Am. J. Applied Sci., 8: 362-367. DOI: 10.3844/ajassp.2011.362.367
AL-Rajab, A.J., L. Sabourin, A. Scott, D.R. Lapen and E. Topp, 2009. Impact of biosolids on the persistence and dissipation pathways of triclosan and triclocarban in an agricultural soil. Sci. Total Environ., 407: 5978-5985. DOI: 10.1016/j.scitotenv.2009.08.003

AL-Rajab, A.J., L. Sabourin, D.R. Lapen and E. Topp, 2010b. The non-steroidal anti-inflammatory drug diclofenac is readily biodegradable in agricultural soils. Sci. Total Environ., 409: 78-82. DOI: 10.1016/j.scitotenv.2010.09.020

AL-Rajab, A.J., L. Sabourin, R. Chapman, D.R. Lapen and E. Topp, 2010a. Fate of the antiretroviral drug tenofovir in agricultural soil. Sci. Total Environ., 408: 5559-5564. DOI: 10.1016/j.scitotenv.2010.07.074

AL-Rajab, A.J., S. Amellal and M. Schiavon, 2008. Sorption and leaching of ${ }^{14} \mathrm{C}$-glyphosate in agricultural soils. Agronomy Sustainable Dev., 28: 419-428. DOI: 10.1051/agro:2008014

Aparicio, V.C., E. De Geronimo, D. Marino, J. Primost and P. Carriquiriborde et al., 2013. Environmental fate of glyphosate and aminomethylphosphonic acid in surface waters and soil of agricultural basins. Chemosphere, 93: 1866-73. DOI: 10.1016/j.chemosphere.2013.06.041, PMID: 23849835

Battaglin, W.A., D.W. Kolpin, E.A. Scribner, K.M. Kuivila and M.W. Sandstrom, 2005. Glyphosate, other herbicides and transformation products in midwestern streams. J. Am. Water Resources Assoc., 41: 323-332. DOI: 10.1111/j.17521688.2005.tb03738.X

Botero-Coy, A.M., M. IBáñEZ, J.V. Sancho and F. Hernández, 2013. Improvements in the analytical methodology for the residue determination of the herbicide glyphosate in soils by liquid chromatography coupled to mass spectrometry. J. Chromatography A, 1292: 132-141. DOI: 10.1016/j.chroma.2012.12.007

Candela, L., J. Álvarez-Benedí, M.T. Condesso De Melo and P.S.C. Rao, 2007. Laboratory studies on glyphosate transport in soils of the maresme area near barcelona, Spain: Transport model parameter estimation. Geoderma, 140: 8-16. DOI: 10.1016/j.geoderma.2007.02.013

Cheah, U.B.K.R.C. and K.Y. Lum, 1998. Degradation of four commonly used pesticides in malysian agricultural soils. J. Agric. Food Chem., 46: 12171223. DOI: $10.1021 /$ jf970579t 
Coquet, Y., 2003. Variation of pesticide sorption isotherm in soil at the catchment scale. Pest. Manage. Sci., 58: 69-78. PMID: 12558101

Coupe, R.H., S.J. Kalkhoff, P.D. Capel and C. Gregoire, 2012. Fate and transport of glyphosate and aminomethylphosphonic acid in surface waters of agricultural basins. Pest. Manage. Sci., 68: 16-30. DOI: $10.1002 / p s .2212$

De Jonge, H.D.J.L.W. and O.H. Jacobsen, 2000. [14C] Glyphosate transport in undisturbed topsoil columns. Pest. Manage. Sci., 56: 909-915.

Dousset, S., C.C. Durlet and M. Thevenot, 2004. Transfert of hexazinone and glyphosate through undisturbed soil columns in soils under Christmas tree cultivation. Chemosphere, 57: 265-272. DOI: 10.1016/j.chemosphere.2004.06.007

Eberbach, P., 1998. Applying non-steady-state compartmental analysis to investigate the simultaneous degradation of soluble and sorbed glyphosate ( $N$-(phosphonométhyl)glycine) in four soils. Pesticide Sci., 52: 229-240.

Getenga, Z.M.K.F.O., 2004. Mineralization of glyphosate in compost-amended soil under controlled conditions. Bull. Environ. Contaminat. Toxicol., 72: 266-275. DOI: $10.1007 / \mathrm{s} 00128-003-9004-9$

Guimont, S., P.G.C. Real and B.M. Schiavon, 2005. Effects of soil moisture and treatment volume on bentazon mobility in soil. Agronomy Sustainable Dev., 25: 323-329. DOI: 10.1051/agro:2005012

Imfeld, G., M. Lefrancq, E. Maillard and S. Payraudeau, 2013. Transport and attenuation of dissolved glyphosate and AMPA in a stormwater wetland. Chemosphere, 90: 1333-1339. DOI: 10.1016/j.chemosphere.2012.04.054

Kryuchkova, Y.V., G.L. Burygin, N.E. Gogoleva, Y.V. Gogolev and M.P. Chernyshova et al., 2014. Isolation and characterization of a glyphosatedegrading rhizosphere strain, Enterobacter cloacae K7. Microbiol. Res., 169: 99-105. DOI: 10.1016/j.micres.2013.03.002

Laitinen, P., S.K. Eronen L. Ramo, S. Welling an d L. Oinonen et al., 2006. Fate of the herbicide glyphosate, glyphosinate-ammonium, phenmedipham, ethofumesate and metamitron in two Finnish arable soils. Pest. Manage. Sci., 62: 473-491. DOI: 10.1002/ps.1186

Landry, D., S. Dousset, J.C. Fournier and F. Andreux, 2005. Leaching of glyphosate and AMPA under two soil management practices in Burgundy vineyards (Vosne-Romanée, 21-France). Environ. Pollut., 138: 191-200. DOI: 10.1016/j.envpol.2005.04.007
Malaguerra, F., H.J. Albrechtsen and P.J. Binning, 2013. Assessment of the contamination of drinking water supply wells by pesticides from surface water resources using a finite element reactive transport model and global sensitivity analysis techniques. J. Hydrol., 476: 321-331. DOI: 10.1016/j.jhydrol.2012.11.010

Mercurio, P., F. Flores, J.F. Mueller, S. Carter and A.P. Negri, 2014. Glyphosate persistence in seawater. Mar Pollut Bull. DOI: 10.1016/j.marpolbul.2014.01.021

Miles, C.J.M.H.A., 1998. Extraction of glyphosate herbicide from soil and clay minerals and determination of residues in soils. J. Agric. Food Chem., 36: 486-491. DOI: 10.1021/jf00081a020

Moreno, N.C., S.H. Sofia and C.B. Martinez, 2013. Genotoxic effects of the herbicide Roundup Transorb and its active ingredient glyphosate on the fish prochilodus lineatus. Environ. Toxicol. Pharmacol, 37: 448-454. DOI: 10.1016/j.etap.2013.12.012

Panettieri, M., L. Lazaro, R. López-Garrido, J.M. Murillo and E. Madejón, 2013. Glyphosate effect on soil biochemical properties under conservation tillage. Soil Tillage Res., 133: 16-24. DOI: 10.1016/j.still.2013.05.007

Struger, J., D. Thompson, B. Staznik, P. Martin and T. Mcdaniel et al., 2008. Occurrence of glyphosate in surface waters of southern ontario. Bull. Environ. Contaminat. Toxicol., 80: 378-84. DOI: 10.1007/s00128-008-9373-1

Van Stempvoort, D.R., J.W. Roy, S.J. Brown and G. Bickerton, 2014. Residues of the herbicide glyphosate in riparian groundwater in urban catchments. Chemosphere, 95: 455-63. DOI: 10.1016/j.chemosphere.2013.09.095

Wiatrak, P. and G. Chen, 2011. Influence of seeding rate on weed density in soybean planting system for southeastern coastal plains. Am. J. Agric. Biol. Sci., 6: 180-184. DOI: 10.3844/ajabssp.2011.180.184

Winkelmann, D.A.K.S.J., 1991. Degradation and bound residues formation of atrazine in a western tennessee soil. Environ. Toxicol. Chem., 10: 335-345. DOI: 10.1002/etc.5620100306 